\title{
CORROSION INHIBITION OF MILD STEEL IN SODIUM CHLORIDE SOLUTION BY NICKEL COMPLEX OF 1-(8-HYDROXY QUINOLIN-2YL- METHYL) THIOUREA
}

\author{
S. S. Syed Abuthahir, ${ }^{1 *}$ K. Vijaya, ${ }^{2}$ A. Jamal Abdul Nasser ${ }^{3}$, C. Karthikeyan ${ }^{4}$ \\ ${ }^{* 1,3}$ Post Graduate \& Research Department of Chemistry Jamal Mohamed College, Tiruchirappalli 620 020, India. \\ Email: syedchem05@gmail.com,ajanasser@yahoo.com \\ ${ }^{2}$ Department of Chemistry, PSNA College of Engineering and Technology, Dindigul, India. Email: \\ hodchemistry@psna.edu.in, ammuviji7@yahoo.co.in \\ ${ }^{1,4}$ RVS School of Engineering and Technology, Dindigul-624 005, Tamilnadu, India. Email: cool.rvs@gmail.com
}

*Corresponding Author: -

Email:syedchem05@gmail.com,ajanasser@yahoo.com

\begin{abstract}
: -
The Corrosion inhibition efficiency of an inhibitor namely Nickel complex of 1-(8-hydroxy quinolin-2ylmethyl) thiourea (Ni-HTF) in controlling corrosion of mild steel immersed in aqueous solution containing $60 \mathrm{ppm} \mathrm{Cl}^{-}$has been investigated by polarization method. The formulation consisting of $60 \mathrm{ppm}$ of $\mathrm{Cl}^{-}$and $50 \mathrm{ppm}$ of Ni-HTF offers good inhibition efficiency of $80 \%$. Polarization study reveals that this formulation functions as a cathodic inhibitor. UV-Visible spectral analysis was used to detect the presence of iron-inhibitor complex. The surface morphology has been analyzed by SEM and EDAX.
\end{abstract}

Key words: Corrosion inhibition, Mild Steel, Polarization, UV-Visible spectroscopy, Transition metal complex, SEM, EDAX and Biocidal Efficiency. 


\section{INTRODUCTION}

Corrosion inhibitors are substances which when added in small concentrations to corrosive media decreases or prevent the reaction of the metal with the media [1]. The use of inhibitors is one of the most practical methods for protecting metals or alloys from corrosion. Compared with inorganic salt corrosion inhibitors, using organic corrosion inhibitors is an effective, inexpensive and less pollution means of reducing the degradation of metals or alloys in many fields of applications and which has been extensively investigated during the last decade [2-8]. It is generally acknowledged that the hetero atoms such as $\mathrm{N}, \mathrm{S}$ and $\mathrm{O}$ in organic compounds show an inhibition effect toward the corrosion of iron, copper and nickel alloys. The main role of hetero atoms in the corrosion protection is the formations of insoluble deposits on inter metallic inclusions. Metal complexes are widely used as catalyst of chemical reactions, e.g. Oxidative dehydrogenation (ODH) of ethane and epoxidation of geraniol [9-11] and as stabilizer or precursor in sol-gel processes [12-14]. Very few works have been performed to study anticorrosive behavior of metal complexes. Harms et al.[15] proposed corrosion inhibition through precipitation of Fe(II) phosphate and Fe(III) phosphate in presence of Fe(III) acetylacetonate and $\mathrm{Fe}$ (II) acetylacetonate respectively. Palladium acetylacetonate is suggested as an effective corrosion inhibitor for water cooled nuclear reactor [16]. Interaction of transition metal complexes with mild steel is greatly affected by their standard electrode potentials, their reactivity and the nature of the ligand that could stabilize the metallic complexes. Reduction of $\mathrm{Cu}$ (II) and Co (II) species on mild steel surface is possible due to their noble standard electrode potential compared to Fe (II). However, it should be noted that negative charged ligands like nitro, thiocyanate, Oxalato, glucinato and acetylacetonate could stabilize the higher oxidation states [17]. The aim of the present work is to evaluate corrosion inhibitive performance of Nickel Complex of 1-(8-hydroxy quinolin-2yl-methyl) thiourea to mild steel immersed in aqueous solution containing $60 \mathrm{ppm} \mathrm{Cl}^{-}$. The corrosion inhibition efficiency was evaluated using weight loss method and electrochemical impedance spectroscopy. The protective film formed on the metal surface characterized with the help of surface analytical techniques such as fluorescence and FTIR spectroscopy.

\section{Materials and Methods}

Mild steel specimens; $(0.026 \% \mathrm{~S}, 0.068 \% \mathrm{P}, 0.36 \% \mathrm{Mn}, 0.13 \% \mathrm{C}$ and the rest iron) of dimensions $1.0 \mathrm{~cm} \times 4.0 \times 0.2 \mathrm{~cm}$ were polished to mirrors finish and degreased with acetone and used for weight loss method.

\section{Potentiodynamic Polarization study}

Polarization studies were carried out in a CHI electrochemical workstation with impedance model 643, Austin, USA. A three electrode cell assembly was used. The working electrode was mild steel. The exposed surface area was $1 \mathrm{~cm}^{2} . \mathrm{A}$ saturated calomel electrode (SCE) was used as the reference electrode and a rectangular platinum foil was used as the counter electrode. The results such as Tafel slopes, $\mathrm{I}_{\text {corr }}, \mathrm{E}_{\text {corr }}$ and LPR values were calculated.

\section{Surface Characterization studies}

The mid steel specimens were immersed in various test solution for a period of one day. After one day the specimens were taken out and dried. The nature of the film formed on the surface of the metal specimen was analyzed by various surface analysis techniques.

\section{Surface analysis by $U V$-Visible spectroscopy}

UV-Visible spectra were recorded in a Cary Eclipse Varian (Model U.3400) spectrophotometer.

\section{SEM Analysis}

SEM (Tescan, Vega 3, USA) provides a pictorial representation in the surface to understand the nature of the surface film in the absence and presence of inhibitors and extent of corrosion of mild steel. The SEM micrographs of the surface are examined.

\section{Energy Dispersive Analysis of X-rays (EDAXs)}

The mild steel specimen immersed in blank and in the inhibitor solution for a period of one day was removed, dried and observed in an Energy Dispersive Analysis of X-rays (EDAXs) to examine the elements presents on the metal surface. The elements present on the metal surface were examined using Bruker computer-controlled Energy Dispersive Analysis of X-rays (Brucker, Nano, GMBH, Germany).

\section{Bacterial Enumeration}

Bacterial cell are count based on their colony forming unit (CFU) by standard plate count. The protocols are as follows. Label the plate $10^{-2}, 10^{-4}, 10^{-6}$ and $10^{-8}$ at the bottom of plate and one plate as a blank or control. Using aseptic technique transfer $1 \mathrm{ml}$ of four different cultures to $99 \mathrm{ml}$ of sterile saline blank. A test tube labelled $10^{-2}$ and the dilution is proceeded by taking $1 \mathrm{ml}$ from $10^{-2}$ test tube to the next $99 \mathrm{ml}$ sterile saline blank labeled as to the next $99 \mathrm{ml}$ sterile saline blank labeled as $10^{-4}$ and proceed until $10^{-8}$. Shake all the test tubes for equal distribution of bacteria. Transfer $1 \mathrm{ml}$ of the sample into each of the labelled plates $10^{-2}$ to $10^{-8}$ correspondingly. Containing agar medium all the plates are immersed and incubate at $37^{\circ} \mathrm{C}$ for 24 hours. After the incubation, select the plate containing 30 to 300 colonies and count the colonies. The number of CFU are calculated as

CFUs/dilution $\times$ amount plated $=$ No.of bacterial cell $/ \mathrm{ml}$. 


\section{Results and Discussion}

\section{Analysis of Polarization Curves}

The polarization study has been used to investigate the formation of protective film on metal surface [18-22].

The polarization curves of mild steel immersed in aqueous solution containing $60 \mathrm{ppm}$ of $\mathrm{Cl}^{-}$are shown in Figure 1 . The corrosion parameters such as Corrosion potential ( $\left.\mathrm{E}_{\text {corr }}\right)$, Corrosion Current density ( $\mathrm{I}_{\mathrm{corr}}$, Tafel slopes $\left(\mathrm{b}_{\mathrm{c}}\right.$ and $\left.\mathrm{b}_{\mathrm{a}}\right)$ and linear polarization curves (LPR) are given in Table 1.

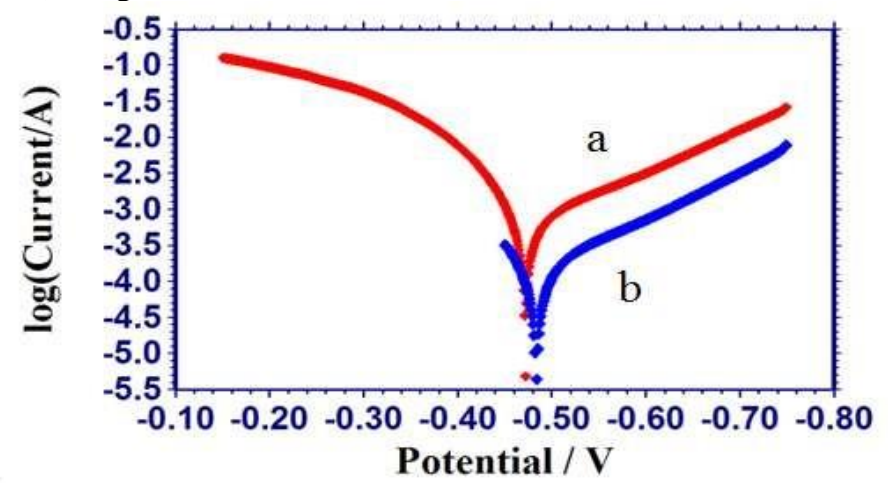

Figure 1. Polarization curves of mild steel immersed in various test solutions: a) Mild steel immersed in aqueous solution containing $60 \mathrm{ppm}^{\circ} \mathrm{Cl}^{-}$b) Mild steel immersed in $60 \mathrm{ppm}$ of $\mathrm{Cl}^{-}+50 \mathrm{ppm}$ of $\mathrm{Ni}$ - $\mathrm{HTF}$

\begin{tabular}{|l|l|l|l|l|l|}
\hline Systems & $\begin{array}{l}\mathrm{E}_{\text {corr }}(\mathrm{mV} \\
\text { vs SCE })\end{array}$ & $\begin{array}{l}\text { Icorr } \\
\left(\mathrm{A} / \mathrm{cm}^{2}\right)\end{array}$ & $\begin{array}{l}\mathrm{b}_{\mathrm{a}} \\
(\mathrm{mV} / \mathrm{dec})\end{array}$ & $\begin{array}{l}\mathrm{bc} \\
(\mathrm{mV} / \mathrm{dec})\end{array}$ & $\begin{array}{l}\text { LPR } \\
\left(\mathrm{ohm}^{2}\right)\end{array}$ \\
\hline $60 \mathrm{ppm} \mathrm{Cl}^{-}$ & -472 & $1.261 \times 10^{-3}$ & 124 & 187 & 25.74 \\
\hline $\begin{array}{l}60 \mathrm{ppm} \mathrm{Cl}+50 \mathrm{ppm} \\
\mathrm{Ni}-\mathrm{HTF}\end{array}$ & -483 & $5.486 \times 10^{-4}$ & 180 & 170 & 132.5 \\
\hline
\end{tabular}

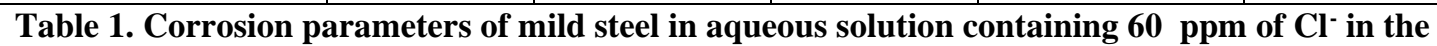
absence and presence of Ni-HTF inhibitor obtained by polarization method.

When mild steel is immersed in aqueous solution containing $60 \mathrm{ppm}$ of $\mathrm{Cl}^{-}$, the corrosion potential is $-472 \mathrm{mV}$

Vs SCE. The formulation consisting of $50 \mathrm{ppm}$ of Ni-HTF shifts the corrosion potential to $-483 \mathrm{mV}$ Vs SCE. It shows that the corrosion potential is shifted to negative side. This suggests that the cathodic reaction is controlled predominantly.

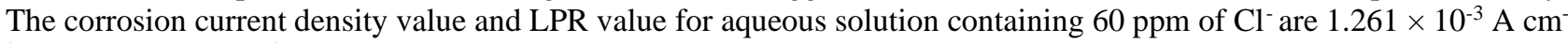
${ }^{2}$ and $25.74 \mathrm{ohm} \mathrm{cm} \mathrm{cm}^{2}$ respectively. For the formulation of $50 \mathrm{ppm}$ of Ni-HTF the corrosion density value has decreased from $1.261 \times 10^{-3} \mathrm{~A} \mathrm{~cm}^{-2}$ to $5.486 \times 10^{-4} \mathrm{~A} \mathrm{~cm}^{-2}$ and the LPR value has increased from $25.74 \mathrm{ohm} \mathrm{cm}^{2}$ to $132.5 \mathrm{ohm} \mathrm{cm}^{2}$. The fact that the LPR value increases with decrease in corrosion current density indicates the absorption of the inhibitor on the metal surface to block the active sites and inhibit corrosion and reduce the corrosion rate with the formation of a protective film on the metal surface.

\section{Analysis of the $U V$-Visible spectra}

The UV-Visible absorption a spectrum of an aqueous solution containing Ni-HTF is shown in figure 2. A peak appears at $356 \mathrm{~nm}$. When $\mathrm{Fe}^{2+}$ solution is added to the solution the intensity of the UV-Visible spectra increases at 580nm. This peak is due to formation of $\mathrm{Fe}^{2+}$-HTF complex in solution [23, 24].

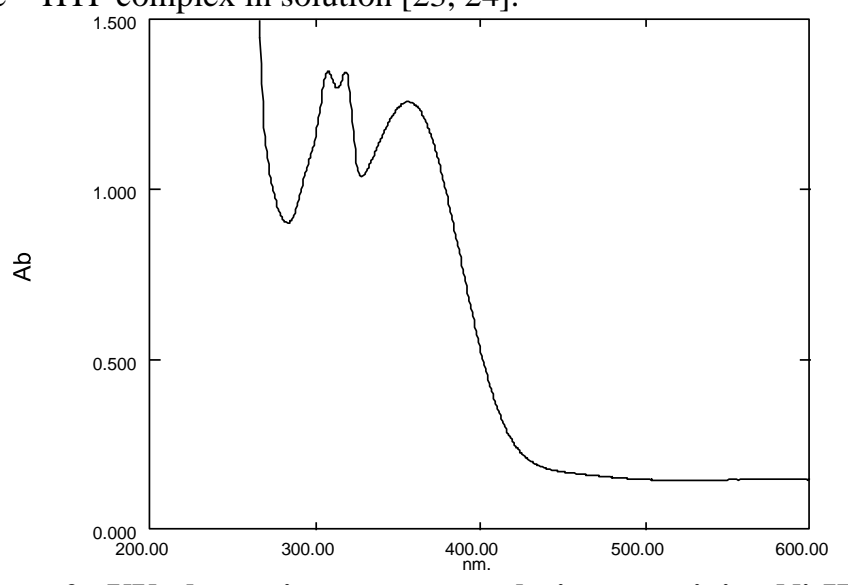

Figure 2a.UV-absorption spectrum solution containing Ni-HTF 


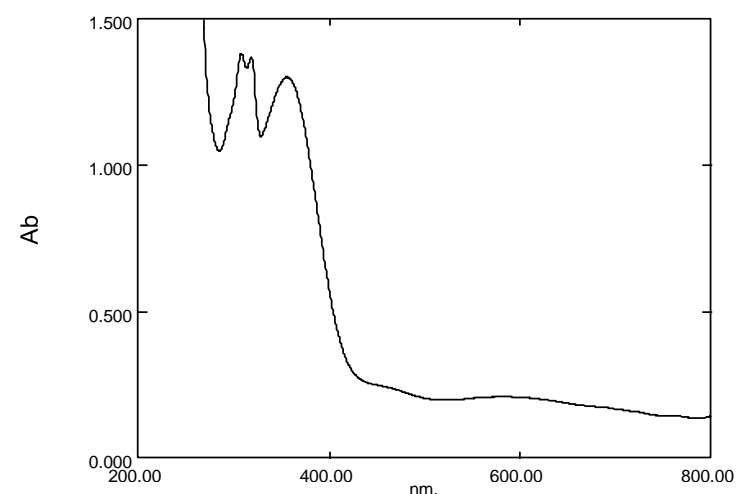

Figure 2b.UV- absorption spectra solution containing HTF-Fe ${ }^{2+}$

It is proposed that oxygen atom of phenolic group and nitrogen atom of pyridine ring have coordinated with $\mathrm{Fe}^{2+}$ formed on the metal surface. The structure of the resulting HTF-Fe ${ }^{2+}$ complex is shown in figure 3.

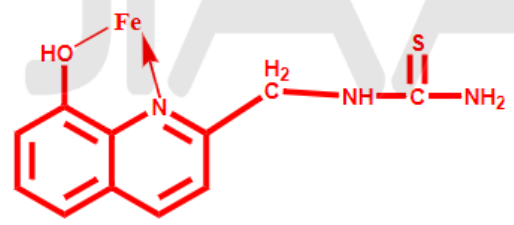

Figure 3. Structure of $\mathrm{Fe}^{2+}$ complex

This view is in agreement with the structure proposed by Albrecht et al. for zinc complex [25].

\section{SEM Analysis of Metal Surface}

SEM provides a pictorial representation of the surface. To understand the nature of the surface film in the absence and presence of inhibitors and the extent of corrosion of mild steel, the SEM micrographs of the surface are examined [2628 ]. The SEM images of different magnification $(\times 20)$ of mild steel specimen immersed in aqueous containing $60 \mathrm{ppm}$ $\mathrm{Cl}^{-}$for one day in the absence and presence of inhibitor system are shown in figures 4(a), 4(b) and 4(c) respectively. The SEM micrographs of polished mild steel surface (control) in figure 4 (a) show the smooth surface of the metal. This shows the absence of any corrosion products (or) inhibitor complex formed on the metal surface. The SEM micrographs of mild steel immersed in aqueous containing 60 $\mathrm{ppm} \mathrm{Cl}^{-}$(Figure 4 (b)) show the roughness of the metal surface which indicates the highly corroded area of mild steel. However, Figure 4 (c) indicates that in the presence of inhibitor $\left(60 \mathrm{ppm} \mathrm{Cl}^{-}+50\right.$ ppm Ni- HTF) the rate of corrosion is suppressed, as can be seen from the decrease of corroded areas. The metal surface is almost free from corrosion due to the formation of insoluble complex on the surface of the metal [26].

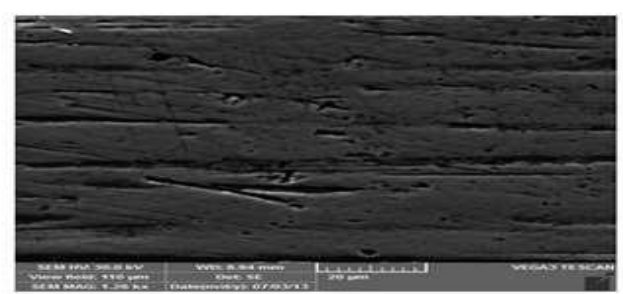

(a)

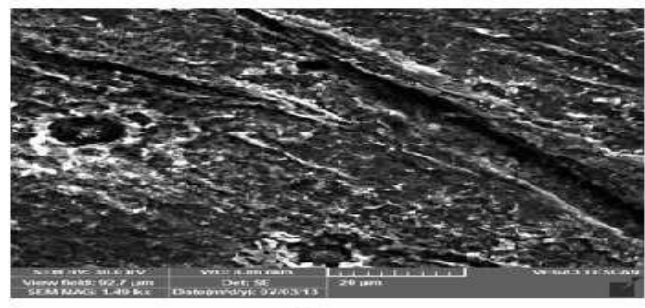

(b)

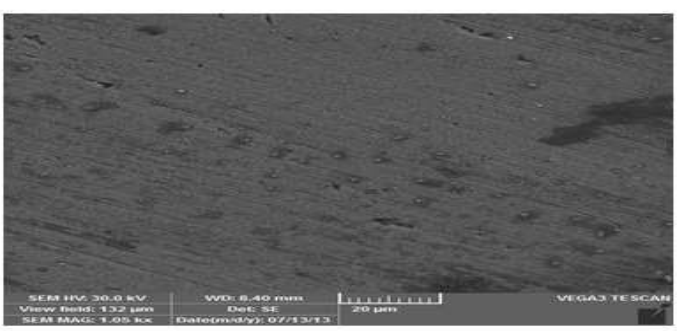

(C)

Figure 4: SEM analysis of mild steel; magnification $\times 20$ (control). (b) Mild steel immersed in aqueous solution containing 60ppm of $\mathrm{Cl}^{-}$, magnification $\times 20$ (blank). (c) Mild steel immersed in aqueous solution containing $60 \mathrm{ppm}$ of $\mathrm{Cl}^{-}+50 \mathrm{ppm}$ of $\mathrm{Ni}$ - HTF magnification $\times 20$

\section{Energy Dispersive Analysis of X-Rays (EDAXs)}

The EDAXs survey spectra were used to determine the elements present on the metal surface before after exposure to the inhibitor solution [27-30]. The objective of this section was to confirm the results obtained from chemical and electrochemical measurements that a protective surface film of inhibitor is formed on the metal surface. To achieve this, EDAX examinations of the metal surface were performed in the absence and presence of inhibitors system [27-30]. 
EDAX spectrum of mild steel immersed in aqueous solution containing $60 \mathrm{ppm} \mathrm{Cl}^{-}$is shown in Figure 5 (a). They show the characteristics peaks of some of the elements constituting the mild steel sample. The EDAX spectrum of mild steel immersed in aqueous solution containing $60 \mathrm{ppm} \mathrm{Cl}^{-}+50 \mathrm{ppm} \mathrm{Ni}$ - HTF is shown in figure 5 (b). It shows the additional line characteristic for the existence of $\mathrm{Ni}$. In addition, the intensity of $\mathrm{O}$ signals is completely varnished and the intensity of Fe signal is increased. The appearance of $\mathrm{Ni}, \mathrm{Fe}$ and other elements signal are due to the presence of inhibitor. These data show that metal surface covered the Fe, S, Ni, P and Mn atoms.

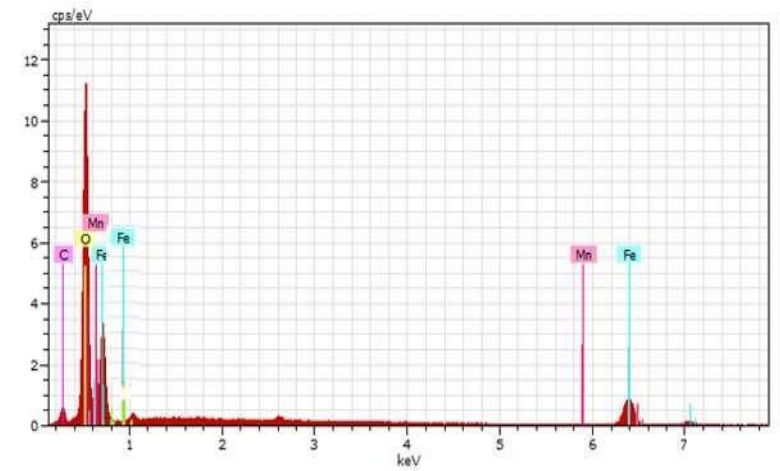

(a)

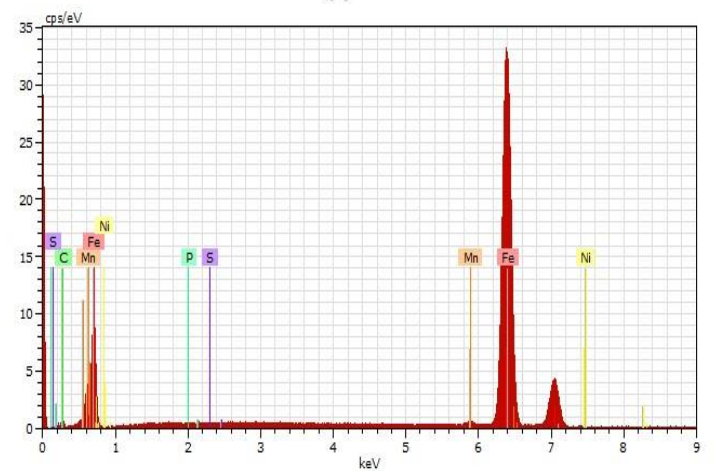

(b)

Figure 5: EDAX spectra of (a) Mild steel sample after immersion in aqueous solution containing $60 \mathrm{ppm} \mathrm{of} \mathrm{Cl}$ . (b) Mild steel sample after immersion in aqueous solution containing $60 \mathrm{ppm}$ of $\mathrm{Cl}^{-}+50 \mathrm{ppm}$ of $\mathrm{Cu}-\mathrm{HTF}$.

\section{Bacterial Enumeration count}

The results of bacterial enumeration count [31] of the aqueous solution containing $60 \mathrm{ppm}^{-} \mathrm{Cl}^{-}$and $60 \mathrm{ppm}$ of $\mathrm{Cl}-$ with Ni-HTF inhibitor are presented in Table 2. The aqueous solution containing $60 \mathrm{ppm}$ of $\mathrm{Cl}^{-}$without inhibitor shows more bacterial count against the growth of pathogenic bacteria strains such as E.Coli, Streptococcus, Pseudomonas and Entrobacter. The aqueous solution containing $60 \mathrm{ppm}^{-} \mathrm{Cl}^{-}$with inhibitor Ni-HTF shows less bacterial count against the growth of pathogenic bacteria strains such as E.Coli, Streptococcus, Pseudomonas and Entrobacter. A good result was obtained when addition of Ni-HTF inhibitor to the corrosive media.

\begin{tabular}{|l|l|l|l|l|}
\hline \multirow{2}{*}{ Systems } & \multicolumn{4}{l|}{ Colonies Forming Unit (per ml) } \\
\cline { 2 - 5 } & E.Coli & Streptococcus & Pseudomonas & Entrobacter \\
\hline $60 \mathrm{ppm} \mathrm{Cl}^{-}$ & $140 \times 10^{6}$ & $146 \times 10^{6}$ & $130 \times 10^{6}$ & $127 \times 10^{6}$ \\
\hline $\begin{array}{l}60 \mathrm{ppm} \mathrm{Cl}^{-}+50 \\
\text { ppm Ni-HTF }\end{array}$ & $49 \times 10^{6}$ & $58 \times 10^{6}$ & $64 \times 10^{6}$ & $63 \times 10^{6}$ \\
\hline
\end{tabular}

Table 2. Colonies forming unit (CFU) of mild steel in aqueous solution containing $60 \mathrm{ppm}$ of $\mathrm{Cl}^{-}$ in the absence and presence of Ni-HTF inhibitor obtained by bacterial enumeration count method.

\section{Conclusion}

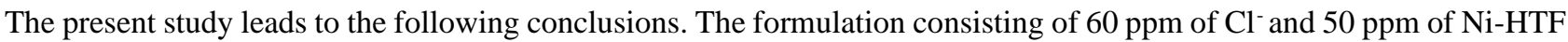
offers $80 \%$ inhibition efficiency in controlling corrosion of mild steel. Polarization study suggests that cathodic reaction is controlled predominantly and reveal that a protective film is formed on the metal surface. UV-Visible spectra reveals that the protective film consists of $\mathrm{HTF}_{-\mathrm{Fe}^{2+}}$ complex formed on metal surface. SEM and EDAX confirm the presence of a protective film on the metal surface. The bacterial enumeration has been reduced by the addition of Ni-HTF inhibitor to the corrosive media. 


\section{Acknowledgement}

The authors are thankful to their management of Jamal Mohamed College, Tiruchirappalli,Tamilnadu, India.

S.S.Syed Abuthahir and Dr.K.Vijaya are thankful to Directors of PSNA College of Engineering and Technology, Dindigul, Tamilnadu, India.

\section{References}

[1]. P.B.Raja, M.G. Sethuraman, Natural products as corrosion inhibitor for metal in corrosive media a review, Mater. Lett, 62 (2008) 113-116.

[2]. M.L. Zheludkevich, K.A. Yasku, S.K. Poznyak, M.G.S. Ferreira, Triazole and thiazole derivatives as corrosion inhibitors for AA204 aluminium alloy, Corros. Sci, 47 (2005) 3368-3383.

[3]. G.Moretti, F.Guidi, G.Grion, Tryptamine as a green iron corrosion inhibitor in $0.5 \mathrm{M}$ deaerated sulphuric acid, Corros. Sci, 46 (2004) 387-403.

[4]. W.J. Guo, S.H.Chen, Y.Y.Feng, C.J,Yang. Investigations of triphenyl phosphate and bis(2-ethylhexyl)phosphate selfassembled films on iron surface using electrochemical methods, Fourier transform infrared spectroscopy, and molecular simulations, J. Phys. Chem, C 111 (2007) 3109-3115.

[5]. K.F.Khaled, Molecular simulation, quantum chemical calculations and electrochemical studies for inhibition of mild steel by triazoles, Electrochim.Acta, 53 (2008) 3484-3492.

[6]. I.Ahamed, M.A. Quraishi, Bis (benzimidazol-2-yl) disulphide: an efficient water soluble inhibitor for corrosion of mild steel in acid media, Corros. Sci, 51 (2009) 2006-2013.

[7]. S.A.Ali, H.A. Al-Muallem, S.U. Rahman, M.T. Saceed, Bis-isoxazolidines: a new class of corrosion inhibitors of mild steel in acidic media, Corros. Sci, 50 (2008) 3070-3077.

[8]. E.M. Sherif, S.M. Park, 2-amino-5-ethyl-1,3,4-thiadiazole as a corrosion inhibitor for copper in $3.0 \% \mathrm{NaCl}$ solutions, Corros.Sci, 48 (2006) 4065-4079.

[9]. L. Cepak, J. Adam, T. Grygar, R. Bulanek, L. Vradman, G. Kosava-Kucerova, P.Cicmanec, P.Knotek, Oxidative dehydrogenation of ethane over vanadium supported on mesoporous materials of M41S family, Appl.Catal.A, 342, (2008) 99-106..

[10]. C.Pereira, A. Rosa Silva, A.Paula Carvalho, J. Pires, C. Freire, Vanadyl acetylacetonate anchored onto aminefunctionalised clays and catalytic activity in the epoxidation of geraniol, J. Mol. Catal. A, 283, (2008) 5-14.

[11]. C. Pereira, S. Patricio, A.Rosa Silva, A.L. Magalhaes, A.Paula Carvahlo, J.Pires, Cristina Freire, Copper acetylacetonate anchored onto amine-funtionalised clays, J. Colloid interf. Sci, 316, (2007) 570-579.

[12]. S. Fujihara, Sol-gel processing of fluoride and oxyfluoride materials, in:H. Kozuka (Ed.), Handbook of Sol-Gel Science and Technology: Volume 1- Sol-Gel Processing, Kluwer Academic Publoshers, (2005) 219.

[13]. M. Cernea, O.Monnereau, P.Llewellyn, L. Tortet, C. Galassi, Sol-Gel synthesis and characterization of Ce doped$\mathrm{BaTiO}_{3}$, J. Eur.Ceram.Soc,. 26, (2006) 3241-3246.

[14]. S.Tangwiwat, S.J.Milne, Barium titanate sols prepared by a diol - based sol-gel route, J.Non-Cryst. Solids, 351, (2005) 976-980.

[15]. H.Harms, H.P. Volkland, G. Repphun, A. Hiltpolt, O. Wanner, A.J.B. Zehnder, Action of chelators on solid iron in phosphate-containing aqueous solutions, Corros. Sci,.45, (2003)1717-1732,

[16]. S. Hettiarachchi, Palladium acetylacetonate solution, European Patent EP0651073, （1995).

[17]. M.Gerloch, E.G.Constable, Transition Metal Chemistry, VCH Verlagsgessellschaft mbH, Weinhein, (1994)176

[18]. Nagalakshmi. R., Rajendran. S., Sathiyabama, J., Pandiarajan, M., Lydia Christy, J., Eur. Chem. Bull, 1(17), (2012), 238.

[19]. Sahayaraja A., Nagalakshmi, R., Rajendran. S., Angelin Thangakani, J., Pandiarajan, M., Eur.Chem. Bull, 1(3), (2012) 130.

[20]. Agiladevi, S., Rajendran, S., Jeyasundari, J., Pandiarajan, M., Eur.Chem.Bull, 2 (2), (2013)503.

[21]. Rajendran, S., Sridevi, S. P., Antony, N., John Amalraj, A., Sundaravadivelu, N., Anto.Corros. Methods Mater, 52,(2005)102.

[22]. Felicia Rajammal Selvarani, Santhanalakshmi, S., Wilson sahayaraja, J., John Amalraj,A., and Rajendran, S., Bull. Electrochem, 20,(2004) 561.

[23]. Rajendran, S., Maria Joany, R., Apparao, B. V. and Palaniswamy, N., Indian J.Chem.Technol., 9, (2002) $197-200$.

[24]. Rajendran s., Earnest John Peter, B. R., Peter Pascal Reces, A., John Amalraj, A. and Sundaravadivelu, M., Trans. SABST, 38(1), (2003) 11-15.

[25]. Markus Albrecht., Karen Witt., Patrick Weis., Elina Wegelius., Roland Frohlich., Inorganica Chimica Acta, 341 (2002) 25-32.

[26]. Gopi D., Manomozhi S., Govindaraju K M., Manisankar P., Rajeswari S., "Surface and Electrochemical characterization of pitting corrosion behavior of 304 stainless steel in ground water media," Journal of Applied electrochemistry, 37, (2007)439-449.

[27]. Amin M A., Abd El-Rehim S S., El-Sherbini E F F., Bayoumi R S, "The inhibition of low Carbon steel corrosion in hydrochloric acid solutions by succinic acid. Part I. Weight loss, Polarization, EIS, PZC, EDX and SEM studies," Electrochimica Acta, 52, (11), (2007) 3588-3600.

[28]. Amin M A., Abd El-Rehim S S.,Abdel- Fatah, "Electrochemical frequency modulation and inductively coupled plasma atomic emission spectroscopy methods for monitoring corrosion rates and inhibition of low alloy steel 
corrosion in $\mathrm{HCl}$ solutions and a test for validity of the Tafel extrplotation method," Corrosion Science, 51, (4) (2009) 882-894.

[29]. Rahim S S A., Hazzazi O A., Amin M A., Khelad K F., "On the corrosion inhibition of low carbon steel in concentrated sulphuric acid solutions. Part I: chemical and electrochemical (AC and DC) studies," Corrosion Science, 50, no. 8, (2008) 2258-2271.

[30]. Migahed M A., Azzam E M S., Morsy S M J., "Electrochemical behavior of carbon steel in acid chloride solution in the presence of dodecyl cysteine hydrochloride self-assembled on gold nanoparticles," Corrosion Science, Vol. 51, no, 8, (2009) 1636-1644.

[31]. Jackie Reynolds/Mark Farinha., Richland College, (2005). 